\title{
Soil Physic and Chemistry Characteristics on Pesticide Application of Soybean Land in Jombang, Lamongan and Probolinggo
}

\author{
Mahanani Tri Asri \\ Department of Biology, Universitas Negeri Surabaya \\ Surabaya, Indonesia \\ mahananiasri@unesa.ac.id \\ Tarzan Purnomo \\ Department of Biology, Universitas Negeri Surabaya \\ Surabaya, Indonesia
}

\author{
Yuliani \\ Department of Biology, Universitas Negeri Surabaya \\ Surabaya, Indonesia \\ Fida Rachmadiarti \\ Department of Biology, Universitas Negeri Surabaya \\ Surabaya, Indonesia
}

\author{
Evie Ratnasari \\ Department of Biology, Universitas Negeri Surabaya \\ Surabaya, Indonesia
}

\begin{abstract}
Applications of pesticides on crop land have been used by soybean land farmer in Jombang, Lamongan and Probolinggo in order to control pest. Pesticide application of soybean land influence physic and chemistry soil, against growth of plant furthermore. This study aimed to identify soil physic and chemistry characteristic on pesticide application of soybean land. This study used sampling purposive method on soybean land in Jombang, Lamongan and Probolinggo District. The data were taken by purposive on pesticide application between pre and post soybean cultivation. Parameters included of soil physic (soil mass, soil porosity, water level, soil texture and determination of soil class), soil chemistry (composition of $\mathrm{C}$-Organic, Total of $\mathbf{N}$, Ratio $\mathbf{C} / \mathbf{N}, P$ and organic matter). The data were analyzed quantitative and qualitative descriptive. Data analysis showed pesticide application of soybean land in Jombang, Lamongan and Probolinggo included intermediate category with composition $1,19-1,25 \mathrm{~g} \mathrm{~cm}^{-3}$ and contain of particle type were $2,30-2,38 \mathrm{~g} \mathrm{~cm}$ 3 , soil porosity accord to ideal land criteria $46,08-49,30 \%$, water level were higher than free capacity limit $(0,33 \mathrm{pF})$ with classification water available, soil texture on $T_{2}$ class were slightly smooth, at every location C-Organic compositions included low category $(0,58-0,94 \%)$, low total of $\mathrm{N}(0,09-0,15 \%), \mathrm{C} / \mathrm{N}$ ratio in low category up to 6-9, $P$ total were varied, from low (J3 dan J2) were $11,90 \mathrm{mgkg}^{-1}$ and $11,94 \mathrm{mgkg}^{-1}$, intermediate $(\mathrm{J} 1, \mathrm{L3}, \mathrm{P2}$ dan P3) up to $19,72-22,59 \mathrm{mgkg}^{-1}$, another three locations $\mathrm{L1}, \mathrm{L2}$, and $P 1$ included of high category, were $36,82-38,48 \mathrm{mgkg}^{-1}$. Organic matters composition.
\end{abstract}

Keywords - soil physic and chemistry characteristics, pesticide, soybean land, Jombang, Lamongan and Probolinggo.

\section{INTRODUCTION}

Pest varieties that recently find on soybean agro ecosystem include soybean leaf pest, leaf beetles, soybean skipper and tobacco cutworm (Spodoptera litura) [1]. Vary of pests infect in crop yield on vary growth of plant stages. Vegetative and generative stages of plant were commonly attacked by pest. For the consequent, farmer has disadvantage with this condition. The farmer effort in order to control pest was apply kind of pesticide accord to its pest. Therefore a one cultivation period could be applies by some of pesticide types. Active ingredients of pesticide which commonly used by farmer in Jombang, Lamongan and Probolinggo were Aceptate, Chlorantraniliprole, Dimehypo, Fenobucarb, Methomyl, Profenofos, Chlorothalonil and Chlorpyrifos (Interview result with soybean farmer, 2018).

Pest control by farmer generally did not follow appropriate instructions. Most of farmer did not use the integrated pest control. Even in some of locations found the uses of pesticide followed by their understanding. Pest control in soybean agro ecosystem on farmer level in East Jaya was using synthetic pesticide [2]. The uses of synthetic pesticide influence against soil nutrition compositions. This was caused by synthetic pesticide included of non biodegradable compound so that accumulate in soils. In long term application will influence the soil fertility and pest resistance.

Soil nutrition compositions by plant included of macro elements as follow Nitrogen $(\mathrm{N})$, Phosphor (P), Potassium (P), Calcium (Ca), Magnesium (Mg), Sulfate (S), Carbon (C), Hydrogen $(\mathrm{H})$ and Oxygen (O) [3]. Those nutrition compositions influences by pesticide level in soil, as an impact of pesticide application by farmer. Therefore, the more varieties of synthetic pesticide those apply by farmer, the higher an effect against availability of soil nutrition. The effect of soil nutrition deficiency, influence their function to its synergist and antagonist against each other elements.

Availability and accumulation of soil pesticide influence soil fertility and characteristics. The study about chemical ingredients effect of pesticide which applies by 
farmer, in case of physic and chemistry soil should be studied furthermore. This study aimed to identification of soil physic and chemistry characteristic on pesticide application of soybean land. The purpose were investigated soil physic characteristics included of soil weight, soil porosity, water level, soil texture and determination of soil class, while the soil chemistry characteristics included of C-organic compositions, Total- $\mathrm{N}, \mathrm{C} / \mathrm{N}$ ratio, organic matters and $\mathrm{P}$ Total in soil, could be uses as recommendation in treatment of continuously and safe environment of agro ecosystem crop yield.

\section{MATERIALS AND METHODS}

This study was undertaken in vitro and in vivo scale, which divided into some stages as follow:

\section{Soil Sampling on Pesticide Application of Soybean Land in Jombang, Lamongan and Probolinggo.}

On this research, soil samples of soybean land taken in Jombang, Lamongan and Probolinggo. Intermediate soybean land of two weeks plants were undertaken in Jombang by high pest infection, soybean in Lamongan were undertaken on flowering stage (2-2.5 months). While soybean plants were on harvest stage around 3 months cultivation under Probolinggo land. Locations sample were undertaken by 3 points which divided into inlet, midlet and outlet location.

\section{Analysis of Characteristic Soil Physic}

Analysis stage of soil physic characteristic was undertaken at Soil Laboratory Faculty of Agriculture, Brawijaya University, Malang. Analysis of soil physics included of soil weight, soil porosity, water level, soil texture and determination of soil class. Soil weight was identified by excavation method, the bucket that contain soils was carried out and weighed by scale, while the soil porosity was gained by flushing method using plezometer. The water level determined by neutron probe, other parameters soil texture investigated by soil conditioner and determination of soil class was using dispersion and sedimentation process, continued with hydrometer method [4].

\section{Analysis of Characteristic Soil Chemistry}

Analysis stage of soil chemistry characteristic was undertaken at Soil Laboratory, Faculty of Agriculture, Brawijaya University, Malang was using method, included of C-organic composition, Total-N, $\mathrm{C} / \mathrm{N}$ ratio, organic matters and total of $\mathrm{P}$ stored. C-organic composition determined by 0,5 gram of soils sample dissolved with $5 \mathrm{ml} \mathrm{K}_{2} \mathrm{Cr}_{2} \mathrm{O}_{7} 1 \mathrm{~N}$, added with $7.5 \mathrm{ml} \mathrm{H}_{2} \mathrm{SO}_{4}$ and aquades. In the next day, the $\mathrm{C}$ organic composition on its solution was determined using spectrophotometer, at $561 \mathrm{~nm}$. Total-N was using distillation method, using $10 \mathrm{ml}$ boric acid, $1 \%$ Conway indicator, $40 \%$ $\mathrm{NaOH}$ and $0,050 \mathrm{~N} \mathrm{H}_{2} \mathrm{SO}_{4}$. $\mathrm{C} / \mathrm{N}$ ratio was gained by standard solution. Determination of organic matters was using hydrogen peroxide, salt and hydrochloric acid oxides. Total of $\mathrm{P}$ stored was using Bray I method, which the reactor were $\mathrm{HCl}$ $5 \mathrm{~N}$, Bray Extraction, $\mathrm{P}$ reactor, $\mathrm{P}$ color reactor and standard solution of $\mathrm{P}$ [5].

\section{RESULTS AND DISCUSSION}

1. Physics Characteristic on Pesticide Application of Soybean Land in Jombang, Lamongan and Probolinggo District.

Soil physic characteristic or soil texture which analyzed include of soil weight, soil porosity, water level, soil texture and determination of soil class. Soil analysis results were examined on Table I.

TABle I. Physic CharaCteristic ON PESTICIDE APPliCATION OF SOYBEAN LAND IN JOMBANG, LAMONGAN AND PROBOLINGGO DISTRICT.

\begin{tabular}{|c|c|c|c|c|c|c|c|c|c|c|c|}
\hline \multirow{2}{*}{\multicolumn{2}{|c|}{$\begin{array}{l}\text { Soil Physic } \\
\text { Parameters }\end{array}$}} & \multicolumn{9}{|c|}{ Soil Samples } & \multirow{4}{*}{$\begin{array}{c}\begin{array}{c}\text { Ideal Land } \\
\text { Criteria* }\end{array} \\
\text { Clay soil typa } \\
-\quad \begin{array}{c}\text { isi } i, 1,0-1,3 \\
\Xi \mathrm{cm} \\
\text { jenis }=2,6 \\
\Xi \mathrm{cm}^{-1}\end{array}\end{array}$} \\
\hline & & J.1 & $\mathrm{J} .2$ & $\mathrm{~J} .3$ & L. 1 & L. 2 & L.3 & P.1 & P.2 & P.3 & \\
\hline \multirow{2}{*}{ 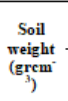 } & Compostion & 1,24 & 1,19 & 1,23 & 1,25 & 1,24 & 1,25 & 1,22 & 1,19 & 1,17 & \\
\hline & Type & 2,30 & 2,30 & 2,31 & 2,36 & 2,38 & 2,32 & 2,32 & 2,30 & 2,31 & \\
\hline \multicolumn{2}{|c|}{ Soil porosity (\%) } & 46,08 & 48,18 & 46,73 & 47,18 & 48,05 & 46,03 & 47,48 & 48,18 & 49,30 & $50 \%$ \\
\hline \multicolumn{2}{|c|}{$\begin{array}{l}\text { Water level pF 2,5 } \\
\left(\mathrm{cm}^{3} \mathrm{~cm}^{3}\right)\end{array}$} & 0,45 & 0,41 & 0,41 & 0,34 & 0,40 & 0,34 & 0,44 & 0,41 & 0,39 & $\begin{array}{l}\text { Free capacity of } \\
\text { water limit } 0,33 \\
\mathrm{pF}\end{array}$ \\
\hline \multirow{3}{*}{$\begin{array}{c}\text { Soil } \\
\text { texture } \\
(\%)\end{array}$} & Sand & 27 & 7 & 32 & 10 & 14 & 11 & 12 & 7 & 7 & \multirow{3}{*}{$\begin{array}{l}\text { Sand }=22,5- \\
52,5 \% \\
\text { Dust }=30-50 \% \\
\text { Clay }=10-30 \%\end{array}$} \\
\hline & Dust & 44 & 34 & 30 & 20 & 22 & 33 & 43 & 34 & 44 & \\
\hline & Clay & 29 & 59 & 38 & 70 & 64 & 56 & 44 & 59 & 49 & \\
\hline \multicolumn{2}{|l|}{ Class } & $\begin{array}{l}\text { Clay } \\
\text { loam }\end{array}$ & Clay & $\begin{array}{l}\text { Clay } \\
\text { loam }\end{array}$ & Clay & Clay & Clay & $\begin{array}{l}\text { Silty } \\
\text { clay }\end{array}$ & Clay & $\begin{array}{l}\text { Silty } \\
\text { clay }\end{array}$ & $\begin{array}{l}\text { T Category } \\
\text { (-lightly smooth } \\
\text { soili): } \\
-\quad \text { Clay } \\
-\quad \text { Clay loam } \\
-\quad \text { Silty clay }\end{array}$ \\
\hline
\end{tabular}

Note : J=Jombang, L=Lamongan, P=Probolinggo; 1,2,3= replication $1,2,3$.

Based on Table 1 showed every soil samples have soil texture with variations of soil physics. Analysis of soil weight showed soil samples that located at Jombang, Lamongan and Probolinggo included of intermediate category with composition up to $1,19-1,25 \mathrm{~g} \mathrm{~cm}^{-3}$ and particle type contains were $2,30-2,38 \mathrm{~g} \mathrm{~cm}^{-3}$.

Porosity analysis has function to determine draination condition and soil aeration at every pesticide application land. Based on analysis of soil porosity showed soybean land in Jombang, Lamongan and Probolinggo have porosity that mostly close to ideal land criteria, 46,08-49,30\% [6]. Therefore soil porosity at three locations of soybean land included good category.

Another analysis of water level on free capacity were 0,34-0,45 $\mathrm{pF}$, this result showed that application pesticide of soybean land water level in Jombang, Lamongan and Probolinggo were higher than free capacity $(0,33)$ [6], with classification water available and capable to absorbs by plant. Those results also showed availability of underground water at three locations were available.

Soil texture analysis showed that soil sample on pesticide application land in Jombang, Lamongan and Probolinggo included of T2 class, which was slightly smooth soil texture. Soil with smooth type related to its high capability in resist water. 
2. Soil Chemistry Characteristic on Pesticide Application of Soybean Land in Jombang, Lamongan and Probolinggo.

Analysis result of chemistry soil (C-organic composition, Total- $\mathrm{N}, \mathrm{C} / \mathrm{N}$ ratio, organic matters and $\mathrm{P}$ total) showed in every location sample have different level (Table II).

TABle 2. SoIl CHEMistry CHARACTERISTIC ON PESTICIDE APPLICATION OF SOYBEAN LAND IN JOMBANG, LAMONGAN AND PROBOLINGGO DISTRICT.

\begin{tabular}{|c|c|c|c|c|c|c|c|c|c|c|c|}
\hline \multirow{2}{*}{ Parameters } & \multicolumn{9}{|c|}{ Location Sample } & \multirow{2}{*}{ Category } & \multirow{2}{*}{$\begin{array}{c}\text { Ideal } \\
\text { Land } \\
\text { Criteria }\end{array}$} \\
\hline & $\mathrm{J} .1$ & $\mathrm{~J} .2$ & $\mathrm{~J} .3$ & L.1 & L.2 & L.3 & P.1 & P. 2 & P.3 & & \\
\hline $\begin{array}{l}\text { C-organic } \\
(\%)\end{array}$ & 0,75 & 0,66 & 0,58 & 0,94 & 0,93 & 0,67 & 0,59 & 0,60 & 0,75 & $\begin{array}{l}\text { Very low } \\
(<0,10) \\
\text { Low }\end{array}$ & $2,01-3,00$ \\
\hline $\begin{array}{l}\text { Total-N } \\
(\%)\end{array}$ & 0,13 & 0,13 & 0,10 & 0,11 & 0,15 & 0,11 & 0,10 & 0,09 & 0,11 & $\begin{array}{l}\text { Very low } \\
(<0,10) \\
\text { Low } \\
(0,10-0,20) \\
\end{array}$ & $0,21-0,50$ \\
\hline $\mathrm{C} / \mathrm{N}$ & 6 & 5 & 6 & 9 & 6 & 6 & 6 & 6 & 7 & Low & $11-15$ \\
\hline $\begin{array}{l}\text { Organic } \\
\text { matters }\end{array}$ & 1,30 & 1,14 & 1,00 & 1,62 & 1,61 & 1,17 & 1,03 & 1,03 & 1,31 & Low & $0,40-10,00$ \\
\hline $\begin{array}{l}\text { P. Bray 19 } \\
\left(\mathrm{mgkg}^{-1}\right)\end{array}$ & 22,59 & 11,9 & 411,90 & 38,48 & 36,8 & 219,83 & 36,85 & 21,64 & 19,72 & $\begin{array}{l}\text { Low }(10-15) \\
\text { Intermediate } \\
(16-25) \\
\text { Very high }(>35)\end{array}$ & $16-25$ \\
\hline
\end{tabular}

Note :

Against dry-oven $105^{\circ} \mathrm{C}$

$\mathrm{J} 1=$ Jombang upsoil layer

J.2 = Jombang soil middle layer

J.3 = Jombang subsoil layer

L.1 = Lamongan upsoil layer

L.2 = Lamongan soil middle layer

L.3 = Lamongan subsoil layer

P.1 = Probolinggo upsoil layer

P.2 = Probolinggo soil middle layer

P.3 = Probolinggo subsoil layer

Based on Table 1 showed that soil from pesticide application of soybean land in Jombang, Lamongan and Probolinggo have C-organic level in very low category [7], which up to $0,54-0,94 \%$. So that included of slightly fertile category. Availability of C-organic influences soil fertility. This is caused by pesticide in soil.

Soil total-N level in pesticide application of soybean land on eight samples at three locations showed low category, $0,10-0,15 \%$ and P2 location sample in Probolinggo included of very low category, $0,09 \%$. This condition was antagonist; availability of $\mathrm{N}$ in soybean land should be highly available, related to the capability of soybean roots as nitrogen free fixer from atmosphere.

$\mathrm{C} / \mathrm{N}$ ratio in soil samples of soybean land at three locations showed low category, 6-9. Decrease of $\mathrm{C} / \mathrm{N}$ ratio influences nutrition availability which followed by soil fertility. Organic matter composition on soybean land in Jombang, Lamongan and Probolinggo showed low contain on all location samples. Organic matters take a vital role on soil texture and nutrition, especially nitrogen, phospor and sulfate. Compositions of organic matter commonly decrease during cultivation and increase through addition of organic/plant residue after harvest in a period [8].
Pesticide application was not conduce an impact as long as its uses properly and controlled, but the effect against life of soil microbe should be noticed. Fertility level in soil agro ecosystem recently depends on the role of microbe populations to convert organic matters. Populations of soil microbe take a role as stabilizator indicator of nutrition availability, in case of soil contaminated by pesticide [9]. Fungi and bacteria were microbe which part of biogeosphere component that has function in mineralization process as soil nutrition stabilizator, so the role of bacteria and fungi in soil also as bioindicator based on life and activity capability from both of microflore [10]. Based on [11] organoclorin group pesticide residue accumulated at topsoil layer $(50 \mathrm{~cm})$, which pressure heterotrophic microbe populations and nitrification bacteria groups, according to soil analysis result of pesticide application land in three locations have nitrogen level and low $\mathrm{C} / \mathrm{N}$ ratio. Some of fungi colony utilizes carbon sources from pesticide residue [12,13], at first fungi were sensitive against pesticide in soil but the fungi were capable in adaptation so that capable to metabolizes normally. Another study from Newton, et al [14] that soil microbe response against pesticide influenced by its chemistry compositions and the effect of pesticide was real against community structure compared to microbe physiology activity.

$\mathrm{P}$ total on locations sample $\mathrm{J} 3$ and $\mathrm{J} 2$ included of low category, were $11,90 \mathrm{mgkg}^{-1}$ and $11,94 \mathrm{mgkg}^{-1}$. Locations of $\mathrm{J} 1, \mathrm{P} 2$ and P3 have $\mathrm{P}$ total at range $19,72-22,59 \mathrm{mgkg}^{-1}$ which included of intermediate category, another three locations were 11, L2 and P1 included of high category up to 36,82$38,48 \mathrm{mgkg}^{-1}$. On rice field frequently total of $\mathrm{P}$ was increase. These processes were resulted by [15]: (a) Ferric phosphate reduction into ferro phosphate which followed by phosphate anion, (b) Chelation of $\mathrm{P}$ related to hydrate of ferric oxide membrane (c) Increase solubility of phosphate ferric and phosphate alluminum caused by $\mathrm{pH}$ increase followed by reduction (d) Dissolution of phosphate from ferric phosphate and alluminium phosphate by organic acid (e) Mineralization organic phosphate (f) Release of phosphate by hydrogen sulfide.

\section{CONCLUSION}

Based on this result it has been concluded that soils on pesticide application of soybean land in Jombang, Lamongan and Probolinggo have weight soil characteristic included of intermediate category with composition 1,19-1,25 $\mathrm{g} \mathrm{cm}^{-3}$ and contain of particle type were $2,30-2,38 \mathrm{~g} \mathrm{~cm}^{-3}$, soil porosity accord to ideal land criteria $46,08-49,30 \%$, water level were $0,34-0,45 \mathrm{pF}$ higher than free capacity limit $(0,33$ $\mathrm{pF}$ ) with classification water available, soil texture on $\mathrm{T}_{2}$ class were slightly smooth, at every location C-Organic compositions included low category $(0,58-0,94 \%)$, low total of $\mathrm{N}(0,09-0,15 \%), \mathrm{C} / \mathrm{N}$ ratio in low category up to 6-9, $\mathrm{P}$ total were varied, from low (J3 dan J2) were 11,90 $\mathrm{mgkg}^{-1}$ and $11,94 \mathrm{mgkg}^{-1}$, intermediate (J1, L3, P2 dan P3) up to $19,72-$ 22,59 $\mathrm{mgkg}^{-1}$, another three locations L1, L2, and P1 included of high category, were $36,82-38,48 \mathrm{mgkg}^{-1}$. 


\section{REFERENCES}

[1] M. Arifin, Bioecology, attack and control of leaf eater pest on soybean leaves. 1992, pp. 81-116, in Marwoto, N. Saleh, Sunardi, dan A. Winarto. (Eds.). Problem of Controlling Pest Integrated in Soybean Plant. Balittan Malang, 8-10 August 1991.

[2] Laoh, J. Hennie, F. Puspita and Hendra, Resistance of Spodoptera litura F. Larvae against Nuclear Polyhedrosist Virus. Pekanbaru: Riau University, 2003.

[3] M. Mutmainah, "Effectivity of Antagonist Bacteria against Fusarium Disease," Sustainable Agriculture Journal, vol. 4, 2015.

[4] Agriculture Development and Research Institute, Soil Physic and Its Analysis Method in Ed. K. Undang, A. Fahmuddin, A. Abdulrachman and D. Ai, Bogor: Agriculture Development and Research Institute, 2006.

[5] Soil Research Institute, Chemistry Analysis of Soil, Plant, Water and Fertilizer in Ed., B. H. Prasetyo, S. Djoko and R. W. Ladiyani, Bogor: Soil Research Institute, 2009.

[6] K.A. Hanafiah, Principle of Soils Study. Jakarta: PT Rajagrafindo Persada, 2005.

[7] S. Hardjowigeno, Study of Soil. Jakarta: CV Akademika Pressindo, 2003.

[8] A. Wild, Soil and The Environment: an Iintroduction. Cambridge: University Press Cambridge, 1993.
[9] P.C. Brookes, "The use of microbial parameters in monitoring soil pollution by heavy metals," Biol. Fertil. Soil., vol. 19, pp. 269-279. March 1995.

[10] M. Cycon and Z. Piotrowska-Seget, "Changes in bacterial diversity and community structure following pesticides addition to soil estimated by cultivation technique," Ecotoxicology, vol. 18, pp. 632-642, July 2009.

[11] M.T. Ahmed, S.M.M. Ismail and S.S. Mabrouk, "Residues of some chlorinated hydrocarbon pesticides in rain water, soil and ground water, and their influence on some soil microorganisms," Env. Int. vol. 24, pp. 665-670, July-August 1998.

[12] D.S. Jenkinson, "The effect of biocidal treatments on metabolism in soil, A method for measuring soil biomass," Soil Biol. Biochem., vol. 8(3), pp. 209-213, 1976.

[13] A.E. Nunez, A. Cabalero and J. Romas, "Boilogical degradation of 2,4.6-trinitrotoluene,” Microb. Mol. Bio. Rev. vol. 65(3), pp. 335-352, September 2001.

[14] Z. Newton, N.Z. Lupwayi, K.N. Harker, L.M. Dosdall, T.K. Turkington, R.E. Blackshaw, J.T. O’Donovan, H.A. Cárcamo, J.K. Otani and G. W. Clayton, "Changes in functional structure of soil bacterial communities due to fungicide and insecticide applications incanola," Agric. Eco. Env., vol. 130 (3-4), pp. 109-114, April 2009.

[15] K. Kyuma, Paddy Soil Science. Kyoto: University Press, Trans Pacific Press, Japan, 2004. 